\title{
Reprint Requests Were Useful in Cardiology Citations
}

\section{Onuigbo WIB*}

Department of Pathology, Medical Foundation \& Clinic, 8 Nsukka Lane, Enugu 400001, Nigeria

${ }^{*}$ Corresponding author: Onuigbo WIB, Department of Pathology, Medical Foundation \& Clinic, 8 Nsukka Lane, Enugu 400001, Nigeria, Tel: +2348037208680, Email: wilson.onuigbo@gmail.com

Citation: Onuigbo WIB (2017) Reprint Requests Were Useful in Cardiology Citations. J Clin Exp Res Cardiol 3(1): 102

Received Date: September 03, 2016 Accepted Date: January 30, 2017 Published Date: Febuary 01, 2017

\begin{abstract}
The study sets out to compare personal studies from 1982 to 2003 as regards 8 articles on the role of the reprint request (RR) in fostering scientific communication. As early as 1986, the Editor of English for Specific Purposes cited the author as "the only active researcher" that he had "traced in the RR area." In this context, 2 papers published in 1972 and 1974 in cardiology were presented together with 4 associated reprints. Actually, the study confirmed the phenomenon of "clustering." Thus, US most active contemporaneous scientists were affiliated in only 8 of the entire states. Out of these, 2 states appeared in the local catchment. In other words, this means that the "tracer tool" function of RR has been demonstrated. However, the Internet is now predominant in such sociological studies; it will no doubt be useful in such tracings.
\end{abstract}

Keywords: Reprints; Requests; Cardiology; Citation; Communication

\section{Introduction}

Personal interest in the importance of the reprint request (RR) led to eight publications between 1982 and 2003 [1-8]. Accordingly, by 1986, Swales [9], the Editor of English for Specific Purposes, cited some of them as an indication of this author being "the only active researcher" that he had "traced in the RR area."

Area of interest of Eugene Garfield, the guru of Information Science, included his vision that USA is the country which mostly publishes works of Third World Scientists [10]. He also noted the important role of citation analysis in scientific communications $[11]$.

\section{Investigation}

Communication in the challenging field of cardiology deserves to be investigated, using the author's publications in this area in both 1972 [12] and 1974 [13]. In sum, the citations concerning both of them should be analyzable. Actually, while the earlier paper was published in USA and was cited only in USA, the other paper appeared in Japan and was cited in Japan as well as in USA notably.

Although the series is still small, it is enough to be subjected to citation analysis in order to ascertain their contributions to knowledge. As regards the 1972 paper [12], it was cited soon after in 1976 in USA [14]. It reported that the author dealt with 4 patients, while they themselves contributed 2 cases, the emphasis being on the importance of our total postmortem findings. They emphasized that both series contained what was not included in a standard text-book of chest diseases. By 1980, another US group [15] credited the contribution in the sense of helping in the understanding of this "extremely unusual" condition.

Furthermore, cardiac cancer supervening on primary lung cancer was published by the author in 1974 [13]. It was cited in 1982 with emphasis thrice in the presentation made by a Japanese group [16]. In particular, they held that the local observation supported the view that the lymphatic system is of the foremost importance. In this context, a US group [17], appreciated also the observed peculiar position of the pericardium in the hierarchy of cardiac involvement.

World-wide citation analysis was grandly surveyed by Garfield [18] who "used the massive Science Citation Index to obtain the 1,000 most-cited contemporary scientists." He found that there was "clustering" in the sense that, out of all the States of America, only 8 produced 25 or more most-cited contemporary scientists. Accordingly, it is of considerable interest that 2 of these States, namely, Connecticut and Tennessee, were those from which requesters arose in the present series concerning only cardiology reprints. Surely, this is a reflection of the author's theory [5] that RR is a "tracer tool" in scientific communications. In other words, RR can trace several disparate factors such as "printer's devil" [1] and "brain drain" [2]. 


\section{Discussion}

This study began with 8 papers in which the importance of RR in communication circles was advocated. It then presented 4 reprints received for the author's 2 articles on cardiology published in 1972 [12] and 1974 [13] respectively. Apart from the ordinary evidence that these papers were used as citation materials properly, there was the extraordinary revelation that the involved RRs came from Connecticut and Tennessee both of which featured among the above 8 American States from which the most-cited contemporary scientists were affiliated. It is concluded that this finding is not a fluke but a fact revealed with the author's personal publications in the field of Cardiology. In all probability, this finding is likely to be confirmed by appealing to the Internet itself, seeing that, since RR seems to be taking the back seat nowadays, it is the growing and dynamic network now readily available [19]. Incidentally, by chance, the author obtained through the Internet the citation of his 1972 article [12] by New York workers [20], i.e., a State that lends further weight to Garfield's "clustering" theory [18]. Moreover, their data showed a positive acceptance of the author's autopsy work in cardiology.

\section{References}

1. Onuigbo WIB (1982) Printer's devil and reprint requests. J Am Soc Inform Sci 33: 58-9.

2. Onuigbo WIB ～(1983) Tracing of brain drain with reprint requests. Soc Biology 30: 423-25.

3. Onuigbo WIB (1984) Utilization of Request-A-Print. Soc Stud Sci 14: 94-6.

4. Onuigbo WIB (1985) Analyzing medicine by means of reprint requests. Meth Inform Med 24: 37-9.

5. Onuigbo WIB (1985) Reprint requests - a tool for documentation. Intl Forum Inform Document 10: 7-9.

6. Onuigbo WIB (1991) Sociological study of surgical sciences with requested reprints. Nig J Surg Sci 1: 40-8.

7. Onuigbo WIB (2003) Fundamental function of reprints in scientific studies. J Coll Med 8: 1-3.

8. Onuigbo WIB (2010) Information discordance in reprints on cancers in "the elderly." Eur Sci Edit 36: 72-3.

9. Swales J. (1986) EST In the big world of reprint requests. English Speci Purposes 5: 81-5.

10. Garfield E (1983) Mapping science in the Third World. Sci Pub Policy 10: 112-7.

11. Garfield E (1977) Citation frequency as a measure of research activity and performance. Essays of Information Scientist, Vol. 1, $1962-1973$.

12. Onuigbo WIB (1972) Direct extension of cancer between pulmonary veins and left atrium. Chest 62: 444-6.

13. Onuigbo WIB (1974) The spread of lung cancer to the heart, pericardium and great vessels. Jap Heart J 15: 234-8.

14. Ciatone RA, Galle JS, Chalwa SK (1980) Carcinoma of the lung invading the left atrium. Connecticut Med 44: 773-6.

15. Stinson JM, Goodwin JV (1976) Pulmonary vein obstruction by bronchogenic carcinoma. South Med J 69: 1482-3.

16. Shinkai T, Tominaga K, Saijo N, Eguchi K, Shimizu E, et al. (1982) The incidence of cardiac metastasis in primary lung cancer and the management of malignant pericardiac effusion. Jap J Clin Oncol 12: 23-32.

17. Adenle AD, Edwards JE (1982) Clinical and pathologic features of metastatic neoplasms of the pericardium. Chest 81: 166-9.

18. Garfield E (1982) The 1000 most-cited contemporary scientists. Part 3. Details on their current intellectual affiliations. Current Contents. Clinical Practice, No.27 5-20.

19. Scandizzo PC, Imperiali A (2014) Internet as a growing and dynamic network: an economic view. Communication Network 6: 69-75.

20. Patane J, Flum DR, McGinn JT, Tyras DH (1996) Surgical approach for renal carcinoma metastatic to the left atrium. Ann Thorac Surg 62: 891-2.

Submit your next manuscript to Annex Publishers and benefit from:

Easy online submission process

$>$ Rapid peer review process

> Online article availability soon after acceptance for Publication

> Open access: articles available free online

More accessibility of the articles to the readers/researchers within the field

Better discount on subsequent article submission

Submit your manuscript at

http://www.annexpublishers.com/paper-submission.php 